\title{
Twist Boat Conformation of Thiane $S$-Oxide Both in Solid State and in Solution
}

\author{
Dong Ju Jeon* and Ikỵon Kim \\ Center for Medicinal Chemistry, Korea Research Institute of Chemical Technologv. Yuseong. Daejeon 305-600. Korea \\ ${ }^{\star}$ E-mail: djeoniakrictre.kr \\ Received April 4. 2008
}

\begin{abstract}
A stable twist boat confonmation of thiane S-oxide 1a in solid state and in solution was unambignously determined by single crystal X-ray crystallography and solution NMR analyses. On the contrary, the thiane $S$ dioxide 2 which was obtained from the oxidation of corresponding thiane $S$-oxide 1a was confinned to adopt a regular chair conformation.
\end{abstract}

Key Words : Twist boat. Conformational analy sis. X-ray crystallography. Thiane S-oxide

\section{Introduction}

It is well-established from calculation studies ${ }^{1}$ and some experimental work $\mathrm{k}^{2}$ that the twist boat conformer is $\sim 5 \mathrm{kcal} /$ mol higher energy state than that of the chair form in cyclohexane ring system. This energy difference, not surprisingly, reflects the preference for the chair conformation over twist boat form. Although some factors are known to be involved in changing this pattern, the literature discloses only a few cases in which a nonchair conformation is observed as a stable form in solution or solid state. In particular, twist-boat conformers in a solid state are rarely known in certain cyclohexanes or saturated 6-menbered heterocycles. ${ }^{3}$

In the course of our study on the reaction of thiane $S$-oxide with various electrophiles. we found that 4-tert-butyl-2diphenylcarbinol thiane $S$-oxide (1a) exists in a twist boat conformation both in a solid state and in solution, while trans-4-tert-butyl-2-diphenylcarbinol thiane S-dioxide (2). bearing a sulfone group in place of the sulfoxide of 1 , exists in a chair form. Herein we wish to report our analy sis on the twist boat structure of thiane S-oxide determined by both $\mathrm{X}$ ray crystallography and solution NMR spectroscopy.

\section{Experimental Section}

Chemistry. ${ }^{1} \mathrm{H}$ NMR and ${ }^{13} \mathrm{C}$ NMR were recorded on JEOL GSX-400 $\left(400 \mathrm{MHz}{ }^{1} \mathrm{H} .100 \mathrm{MHz}{ }^{13} \mathrm{C}\right)$, JEOL EX$270\left(270 \mathrm{MHz}{ }^{1} \mathrm{H} .67 .8 \mathrm{MHz}{ }^{13} \mathrm{C}\right)$ spectroneters. Tetramethylsilane was used as an internal standard. IR spectra were recorded on Jasco IRA-1 or Jasco IR Report-100 spectrometers. Peaks are reported in units of $\mathrm{cm}^{-1}$. Mass spectra (LMS) were recorded on a JEOL JMS-01 mass spectrometer, and HRMS were recorded on a DX-300 mass spectrometer under electron inmpact (EI) conditions. Reactions were monitored by thin-layer chromatography carried out on $0.25 \mathrm{~mm}$ Merck silicagel plates $(60 \mathrm{~F}-254)$ with UV light. Melting points were determined on a Buchi 510 melting point apparatus and are uncorrected. For anlydrous reactions. THF, ether. DME, and toluene were distilled from sodium metal benzophenone ketyl.
Synthesis of trans-t-tert-butyl-2-diphenylcarbinol thiane-S-0xide (1a) and cis-4-tert-butyl-2-diphenylcarbinol thiane-S-oxide (1b): To a stirred solution of disopropyl amine $(0.46 \mathrm{~mL}, 3.3 \mathrm{mmol})$ in THF $(30 \mathrm{~mL})$, precooled at $-78{ }^{\circ} \mathrm{C}$ under nitrogen atmosphere, was added a $1.62 \mathrm{~N}$ solution of $\mathrm{n}-\mathrm{BuLi}$ in hexane $(2.0 \mathrm{~mL} .3 .3 \mathrm{mmol})$. After the resulting solution was stirred at $-78^{\circ} \mathrm{C}$ for $30 \mathrm{~min}$. a solution of trans-4-tert-butylthiane $S$-oxide $(0.47 \mathrm{~g} .2 .8 \mathrm{mmol})$ in THF $(3 \mathrm{~mL})$ was added dropwise during a period of about 3 $\mathrm{min}$. After stirring for $30 \mathrm{~min}$ at $-78^{\circ} \mathrm{C}$. benzophenone $(1.3$ g. $7.3 \mathrm{mmol}$ ) was added. and the whole was stirred for $\mathrm{l} h$ at $-78^{\circ} \mathrm{C}$. The reaction mixture was quenched with satd. aq $\mathrm{NH}_{4} \mathrm{Cl}$ and allowed to warm to room temperature. After addition of 5\% hydrochloric acid and followed by extraction with ethyl acetate three times. the combined organic layers were washed with brine, dried over magnesium sulfate. filtered. and evaporated. The crude products were purified by silica gel column cluromatography (ethyl acetate $/ \mathrm{MeOH}$ $=20 / 1)$ to give $1 \mathrm{a}(0.31 \mathrm{~g} .33 \%)$ and $1 \mathrm{~b}(0.37 \mathrm{~g} .39 \%)$ as a colorless solid.

Spectra of trans-4-tent-butyl-2-diphenylcarbinol thiane-Soxide (1a): ${ }^{1} \mathrm{H}$ NMR $\left(400 \mathrm{MHz}, \mathrm{CDCl}_{3}\right): \delta 7.70-7.76(10 \mathrm{H}$. m. Ar). 5.55 (lH. s, OH). 3.48 (lH. dd. $J=10,4 \mathrm{~Hz}, \mathrm{C}=\mathrm{H}$ ), $3.17\left(\mathrm{lH}\right.$, ddd, $\left.J=14.7 .4 \mathrm{~Hz} . \mathrm{C}_{6}-\mathrm{H}_{\mathrm{eq}}\right), 2.69(1 \mathrm{H}, \mathrm{ddd}, J=$ $14,10.4 \mathrm{~Hz} . \mathrm{C}_{6}-\mathrm{H}_{\mathrm{ax}}$ ). 2.46 (1H. ddd. $J=15,10.7 \mathrm{~Hz} . \mathrm{C}_{3-}$ $\left.\mathrm{H}_{\mathrm{eq}}\right) .2 .05-1.92\left(2 \mathrm{H}, \mathrm{m}, \mathrm{C}_{4}-\mathrm{H} . \mathrm{C}_{5}-\mathrm{H}_{\mathrm{eq}}\right), 1.6 \mathrm{l}(\mathrm{lH}, \mathrm{dt}, J=15.5$ Hz. $\left.\mathrm{C}_{3}-\mathrm{H}_{\mathrm{ax}}\right) .1 .40\left(\mathrm{lH}, \mathrm{m} . \mathrm{C}_{-}-\mathrm{H}_{\mathrm{ax}}\right) \cdot 0.74(9 \mathrm{H}, \mathrm{s}, t-\mathrm{Bu}):{ }^{13} \mathrm{C}$ $\operatorname{NMR}\left(67.5 \mathrm{MHz} . \mathrm{CDCl}_{3}\right): \delta 145.86$ (s), 144.55 (s), 128.41 (d) 128.18 (d) 127.24 (d) 126.83 (d), 125.80 (d). 125.18 (d). 80.70 (s). 56.14 (d), 46.45 (t), 40.33 (d), 33.59 (s), 27.32 (q), 18.69 (t). 17.20 (t); MS: m/z $356\left(\mathrm{M}^{-}\right)$: IR (KBr) ( $\left(v_{\text {max }}\right)$ : $3400.1598,1050.985 .978 .945 \mathrm{~cm}^{-1}$ : mp: $171-171.5^{\circ} \mathrm{C}$. Spectra of cis-4-tert-butyl-2-diphenylcarbinol thiane-Soxide (1b): ${ }^{1} \mathrm{H}$ NMR $\left(400 \mathrm{MHz} . \mathrm{CDCl}_{3}\right): \delta 7.56-7.26(10 \mathrm{H}$, m. Ar), 6.06 (lH. s. OH). 3.65 (lH. d. $J=12 \mathrm{~Hz}$. $\mathrm{C}_{2}-\mathrm{H}_{\mathrm{ax}}$ ), $3.39\left(\mathrm{lH}\right.$, ddd, $\left.J=12.4 .3 \mathrm{~Hz} . \mathrm{C}_{6}-\mathrm{H}_{\text {eq }}\right), 2.91(1 \mathrm{H}, \mathrm{ddd}, J=$ $\left.12,12,3 \mathrm{~Hz}, \mathrm{C}_{6}-\mathrm{H}_{\mathrm{ex}}\right) .2 .10\left(2 \mathrm{H}, \mathrm{m} . \mathrm{C}_{3}-\mathrm{H}_{\mathrm{eq}}, \mathrm{C} .5-\mathrm{H}_{\mathrm{eq}}\right) .1 .46-$ $1.33\left(2 \mathrm{H} . \mathrm{m}, \mathrm{C}_{4}-\mathrm{H}_{2 \times}, \mathrm{C}_{5}-\mathrm{H}_{\mathrm{ax}}\right), 1.07$ (lH. ddd. $J=15.12 .2,12$ Hz. $\left.\mathrm{C}_{3}-\mathrm{H}_{\mathrm{as}}\right), 0.78\left(9 \mathrm{H}\right.$. s, $t$-Bu); ${ }^{13} \mathrm{C}$ NMR $(67.5 \mathrm{MHz}$, $\left.\mathrm{CDCl}_{3}\right): \delta 143.58$ (s), 141.96 (s), 128.25 (d), 127.85 (d). 127.82 (d). 126.76 (d). 127.73 (d). 127.55 (d), 82.21 (s). 
$71.56(d), 52.31(t) .48 .23(d), 32.40(s), 28.21(t), 27.23(q)$. $24.87(\mathrm{t}): \mathrm{MS}: \mathrm{m} / \mathrm{z} 356\left(\mathrm{M}^{+}\right)$; IR (KBr) $\left(\mathrm{cm}^{-1}\right)$ : 3300.1598. 1030. 1018, 1000: nip: $168-169^{\circ} \mathrm{C}$.

Synthesis of trans-4-tert-butyl-2-diphenylcarbinol thiane-S-dioxide (2): To a stirred solution of of trans-t-tertbutyl-2-diphenylcarbinol thiane-S-oxide (1a) $(0.19$ g. 0.53 mmol) in methylene chloride (5 mL) added slowly $70 \%$ MCPBA $(2.00 \mathrm{~g} .0 .79 \mathrm{mmol})$ at cooling with an ice bath. After stirring for $3 \mathrm{~h}$ at room temperature. aqueous $15 \%$ $\mathrm{NaOH}$ solution $(3 \mathrm{~mL})$ was slowly added and the mixture was extracted with ethyl acetate $(10 \mathrm{~mL})$ twice. The combined organic layer was washed with aqueous $15 \% \mathrm{NaOH}$ solution and brine twice respectively, and dried over anhy. drous sodium sulfate. evaporated to obtain $\mathbf{2}$ as a colorless solid $(0.25$ g. $67 \%)$.

Spectra of trans-4-tert-butyl-2-diphenylcarbinol thiane $S$ dioxide (2): ${ }^{1} \mathrm{H} \mathrm{NMR}\left(300 \mathrm{MHz} . \mathrm{CDCl}_{3}\right): 87.58-7.17(10 \mathrm{H}$. m, Ar). 4.37 (lH. m. C.-H), 3.81 (lH. s. OH). $3.37(1 \mathrm{H}, \mathrm{td}, J$ $\left.=13,4 \mathrm{~Hz}, \mathrm{C} 6 \mathrm{H}_{\mathrm{eq}}\right), 2.69\left(1 \mathrm{H}, \mathrm{m}, \mathrm{C}_{6}-\mathrm{H}_{\mathrm{ax}}\right) 2.11-1.71(5 \mathrm{H} . \mathrm{m}$. $\left.\mathrm{C}_{3.4 .5}-\mathrm{H}\right) .0 .59(9 \mathrm{H} . \mathrm{s}, t-\mathrm{Bu}) ;{ }^{13} \mathrm{C}$ NMR $\left(67.5 \mathrm{MHz}, \mathrm{CDCl}_{3}\right): \delta$ 146.36 (s), 144.02 (s). 128.39 (d), 128.29 (d), 127.40 (d). 126.93 (d). 125.80 (d). 125.42 (d), 79.00 (s), 64.64 (d), 53.14 (t). 39.31 (d). 32.58 (s). 27.37 (q). 26.84 (t). 24.30 (t): MS: $\mathrm{m} / \mathrm{z} 372\left(\mathrm{M}^{-}\right) ; \mathrm{IR}(\mathrm{KBr})\left(\mathrm{cm}^{-1}\right): 3458.1597,1338,1292$. 1285. $1161.1142 .1111 \mathrm{~cm}^{-1}: \mathrm{mp}:>230^{\circ} \mathrm{C}$.

\section{Results and Discussion}

As shown in Scheme 1, treatment of trans-t-tert-butylthiane $S$-oxide ${ }^{4}$ with LDA at $-78^{\circ} \mathrm{C}$ followed by benzophenone in THF produced a nixture of diastereomers, trans-4tert-butyl-2-diphenylcarbinol thiane S-oxide (1a) and cis-4tert-butyl-2-diphenylcarbinol thiane S-oxide (1b). which were separated by silica gel colunn chromatography in $33 \%$ and $39 \%$ yields. respectively.

Compound 1a was recrystallized from methanol to obtain the colorless crystals, mp $171-171.5^{\circ} \mathrm{C}$. Elemental analysis was obtained within +0.3 of calculated value. Trans-4-tertbutyl-2-diphenyylcarbinol thiane S-dioxide (2) was synthe- sized by the oxidation of 1a using mCPBA in dichloromethane at room temperature and recrystallized from a mixture of isopropyl alcohol and chloroform (2:1) as a solvent to give the colorless cry stals in $83 \%$ yield. mp $>230$ ${ }^{\circ} \mathrm{C}$. C and $\mathrm{H}$ analyses within +0.3 of calculated value were obtained.

Single-crystal X-ray diffraction analyses for $\mathbf{1 a}$ and $\mathbf{2}$ were performed by a $\mathrm{P} 4 \mathrm{X}$-ray diffractometer (Siemens $\mathrm{Co}$.) and the crystal data and structure refunement are listed in Table 1.5

The thiane ring of 1a is highly distorted, as shown in Figure 1 , and the examination of the tortional angles in Table 2 reveals that the tert-butyl and dipheny lcarbinol group of 1a occupy the pseudoequatorial positions, while a sulfoxide group the pseudoaxial position. To the best of our knowledge, twist boat form as a preferred structure in the thiane $S$ oxide system is unprecedented. The twisted confonmation of the thiane ring of $1 \mathrm{a}$ is further reflected in the long bond for $\mathrm{S}(1)-\mathrm{C}(1)(1.812 \mathrm{~A}) . \mathrm{S}(1)-\mathrm{C}(5)(1.812 \mathrm{~A}), \mathrm{C}(3)-\mathrm{C}(4)(1.531$
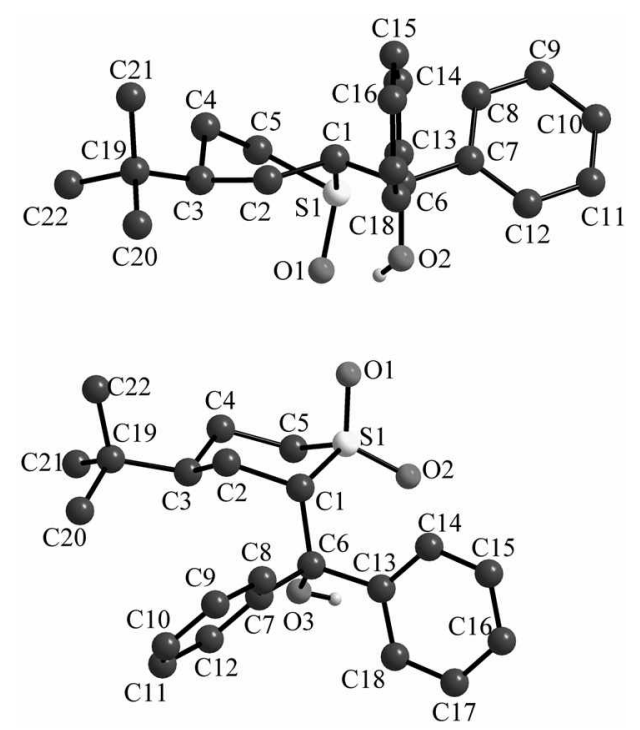

Figure 1. ORTEP drawings of $1 \mathbf{a}$ and 2.

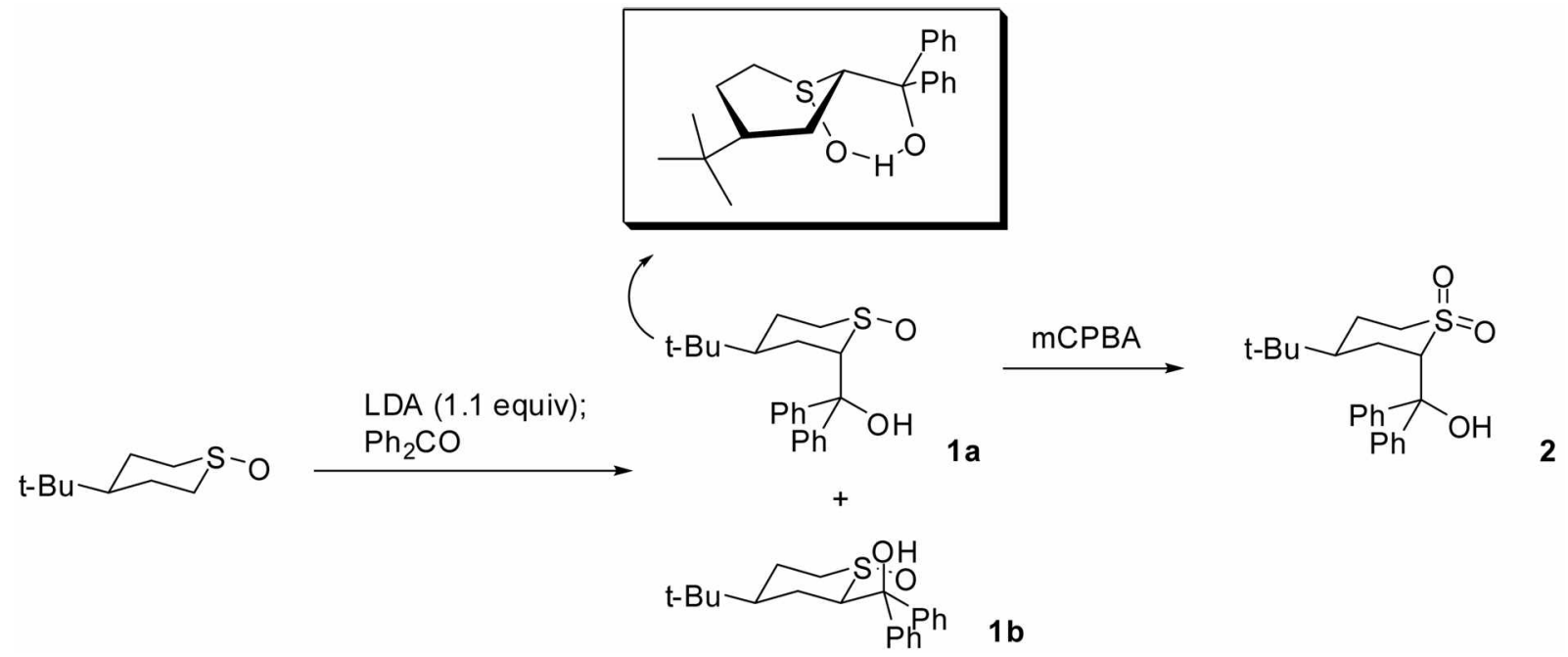

Scheme 1. Synthesis of 1 and 2. 
Table 1. Crystal Data for 1a and 2

\begin{tabular}{|c|c|c|}
\hline & $1 \mathbf{a}$ & 2 \\
\hline tormula & $\mathrm{C}_{22} \mathrm{H}_{28} \mathrm{O}_{2} \mathrm{~S}$ & $\mathrm{C}_{22} \mathrm{H}_{28} \mathrm{O}_{2} \mathrm{~S}$ \\
\hline formula weight & 356.50 & 372.50 \\
\hline crystal size (mun) & $0.3 \times 0.3 \times 0.3$ & $0.4 \times 0.3 \times 0.2$ \\
\hline space group & $\mathrm{p}_{2} / \mathrm{c}$ & $p 2_{1} / \mathrm{s}$ \\
\hline \multirow[t]{6}{*}{ unit cell dimensions } & $a=10.4870(14) A$ & $a=10.929(2) \mathrm{A}$ \\
\hline & $b=10.6344(12) A$ & $b=11.064(2) \mathrm{A}$ \\
\hline & $c=18.273(2) \mathrm{A}$ & $c=16.204(3) \mathrm{A}$ \\
\hline & $\alpha=90^{\circ}$ & $\alpha=90^{\circ}$ \\
\hline & $\beta=103.20(2)^{\circ}$ & $\beta=91.388(12)^{\circ}$ \\
\hline & $y=90^{\circ}$ & $\gamma=90^{\circ}$ \\
\hline density (calculated) & $1.193 \mathrm{Mg} / \mathrm{m}^{3}$ & $1.263 \mathrm{Mg} / \mathrm{m}^{2}$ \\
\hline wavelength & $0.71073 \mathrm{~A}$ & $0.71073 \mathrm{~A}$ \\
\hline data/restraints/parameters & $3498 / 0 / 226$ & $3443 / 0 / 236$ \\
\hline \multirow[t]{2}{*}{ final $R$ indices $[I>2(I)]$} & $\mathrm{Rl}=0.0505$ & $\mathrm{Rl}=0.0618$ \\
\hline & $\mathrm{wR} 2=0.1095$ & $\mathrm{wR} 2=0.1364$ \\
\hline \multirow[t]{2}{*}{$\mathrm{K}$ indices (all data) } & $\mathrm{Rl}=0.0909$ & $\mathrm{R} 1=0.1115$ \\
\hline & $\mathrm{wR} 2=0.1274$ & $\mathrm{wR} 2=0.1588$ \\
\hline goodness-of-fit on $\mathrm{F}^{2}$ & 1.016 & 1.024 \\
\hline $\max /$ min. transmission & $0.3106 / 0.2925$ & $0.2653 / 0.2426$ \\
\hline
\end{tabular}

A). and $\mathrm{C}(4)-\mathrm{C}(5)(1.535 \mathrm{~A})$. The unusually large bond angles for $\mathrm{C}(2)-\mathrm{C}(1)-\mathrm{S}(1)\left(116.8^{\circ}\right)$ and $\mathrm{C}(3)-\mathrm{C}(4)-\mathrm{C}(5)$ $\left(116.8^{\circ}\right)$ in the ring also clarifies the twisted conformation.

On the other hand, the thiane ring of 2 exists in a chair conformation. where the tert-butyl group occupies the equatorial position and diphenylcarbinol group exists in the axial position.

Although structural differences between 1a and 2 only stem from the difference in oxidation state (sulfoxide $w$. sulfonyl group), the conformations are twist boat and chair forms in 1a and 2, respectively. Since sulfoxide prefers to occupy the axial position, ${ }^{7}$ it seemed to play some role in taking twisted conformation in 1a. but the preference energy of the axial type of sulfoxide to an equatorial type in the thiane $S$-oxide is generally known to be $\sim 0.2 \mathrm{kcal} / \mathrm{mol}^{8}$. which is too small when compared with the preference energy of chair form over twist boat form $(\sim 5 \mathrm{kcal} / \mathrm{mol})$ in the cyclohexane ring system. Another factor for taking the twist form in 1a is seen in the intramolecular hydrogen bonding between the sulfoxide oxygen and the hydroxyl groups. which is observed in the crystal structure of Figure 1
Table 2. Tortional Angles for Thiane Ring of $\mathbf{1 a}$ and 2

\begin{tabular}{lrr}
\hline & \multicolumn{1}{c}{$1 \mathbf{a}$} & \multicolumn{1}{c}{2} \\
\hline$C(5)-S(1)-C(1)-C(2)$ & $21.35(0.24)$ & $-49.56(0.33)$ \\
$S(1)-C(2)-C(3)-C(4)$ & $38.54(0.30)$ & $59.06(0.41)$ \\
$C(1)-C(2)-C(3)-C(4)$ & $-69.55(0.28)$ & $-62.04(0.41)$ \\
$C(2)-C(3)-C(4)-C(5)$ & $28.12(0.31)$ & $65.86(0.40)$ \\
$C(3)-C(4)-C(5)-S(1)$ & $37.80(0.28)$ & $-59.16(0.34)$ \\
$C(4)-C(5)-S(1)-C(1)$ & $-58.99(0.20)$ & $46.67(0.27)$ \\
\hline
\end{tabular}

for $\mathrm{O}(\mathrm{l})-\mathrm{H}-\mathrm{O}(2)(\mathrm{O}(\mathrm{l}-\mathrm{H}$ distance: $2.280 \mathrm{~A}: \mathrm{O}(\mathrm{l})-\mathrm{H}-\mathrm{O}(2)$ angle: $129.37^{\circ}$ ). whereas hydroxyl of 2 does not engage in the intramolecular hydrogen bonding with the sulfone functionality.

Intenal hydrogen bonding of the hydrosy proton of 1a was also detected in solution $\left(\mathrm{CDCl}_{3}\right)$ as follows: the hydroxy proton chemical slift $(5.6 \mathrm{ppm})$ of $1 \mathrm{a}$ appeared down field compared with the hydroxy proton of 2 (3.8 ppm): moreover, the hydroxy proton of 1a was unchanged in various concentrations (0.1 M- $0.01 \mathrm{M})$. Conclusively, we suggest that three factors such as (1) axial preference of sulfoxide, (2) equatorial preference of diphenylcarbinol, and (3) hydrogen bonding between sulfoxide oxygen and hydroxyl. which forms like a [6.6] bicyclic structure ( $\mathrm{S}(1)$ $\mathrm{C}(1)-\mathrm{C}(2)-\mathrm{C}(3)-\mathrm{C}(4)-\mathrm{C}(5)-\mathrm{C}(10)-\mathrm{O}(2)-\mathrm{H}-\mathrm{O}(1))$ work cooperatively for twist boat conformation of $1 \mathrm{a}^{\mathrm{y}}$

The confonmation of $1 \mathrm{a}$ in solution $\left(\mathrm{CDCl}_{3}\right)$ was examined as well. Indeed, solution NMR study indicated that the preferred conformation of $1 \mathrm{a}$ in $\mathrm{CDCl}_{3}$ is a twist boat form like the one observed in the crystal for the following reasons: (1) The sulfoxide of 1a (Figure 2) is confirmed to be oriented axially ${ }^{13}$ since large upfield shifts of $\mathrm{C}_{2}=\mathrm{H}(3.48$ ppm) and $\mathrm{C}_{\text {tes }}-\mathrm{H}(3.17,2.69 \mathrm{ppm})$ of 1 a were observed. which is comparable to those of the $\mathrm{C}_{2}-\mathrm{H}(3.65 \mathrm{ppm})$ and $\mathrm{C}_{1, \mathrm{kl}} \mathrm{H}(3.39,2.91 \mathrm{ppm})$ of $\mathbf{1 b}$ in ${ }^{1} \mathrm{H}$ NMR. In addition, large upfield shifts of $C_{2}(56.07 \mathrm{ppm})$ and $\mathrm{C}_{6}(46.42 \mathrm{ppm})$ of 1 a were observed in ${ }^{13} \mathrm{C}$ NMR as were $C_{2}(71.50 \mathrm{ppm})$ and $\mathrm{C}_{6}(52.33 \mathrm{ppm})$ of $\mathbf{1 b} .^{1]}$ (2) Downfield slifts of $\mathrm{C}_{4}=\mathrm{H}$ (1.96 ppni) and $\mathrm{C}_{34.32}-\mathrm{H}(2.46,1.62 \mathrm{ppm})$ in $1 \mathrm{a}$ in ${ }^{\mathrm{l}} \mathrm{H}$ NMR $\left[\mathrm{C}_{4}-\mathrm{H}\right.$ $(1.37 \mathrm{ppm}), \mathrm{C}_{34}, 3 . \mathrm{H}(1.07,2.10 \mathrm{ppm})$ in 1b] are in harmony with the $\mathrm{X}$-ray crystal structure. where $\mathrm{C}_{4}-\mathrm{H}$ and $\mathrm{C}_{3}-\mathrm{H}$ are in the position affecting anisotropy of sulfoxide. ${ }^{12}$ (3) Some coupling constants of the thiane ring in 1 a represent the
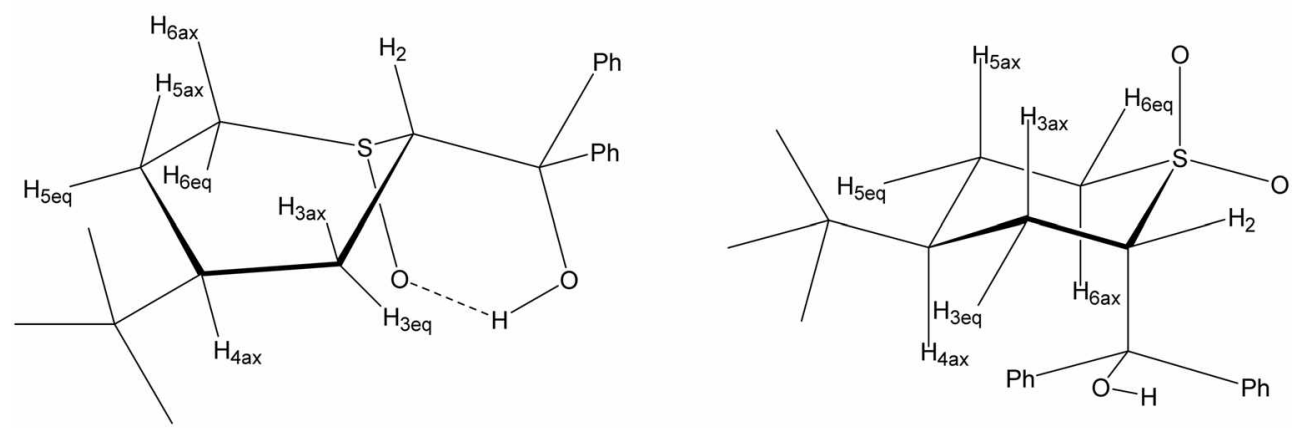

Figure 2. Structures of 1a and 2. 


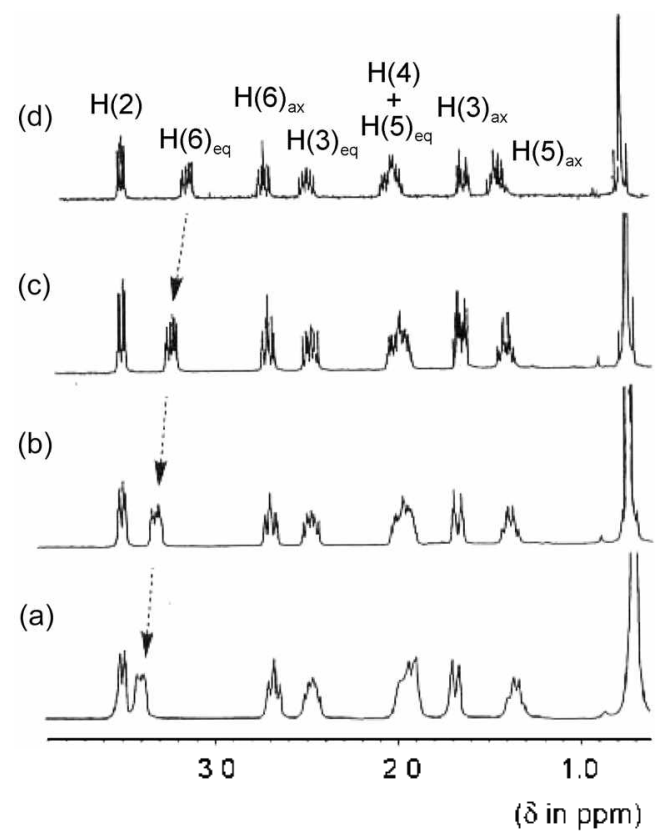

Figure 3. ${ }^{1} \mathrm{H}$ NMR of 1 a at various temperatures (a) $-70^{\circ} \mathrm{C}$ (b) -40 ${ }^{\circ} \mathrm{C}(\mathrm{c}) 0^{\circ} \mathrm{C}(\mathrm{d}) 60^{\circ} \mathrm{C}$.

twisted conformation in ${ }^{1} \mathrm{H}$ NMR where internal dihedral angles are inclined to be sniall as seen in the crystal structure. and by the Karplus equation, the vicinal proton coupling constants of axial-axial relationship of $1 \mathrm{a}$ are to be smaller than those of $\mathbf{1 b}\left(J_{\text {a } 3 \mathrm{a}}=10 \mathrm{~Hz}\right.$ and $12 \mathrm{~Hz}$ in $1 \mathrm{a}$ and 1b. $J_{5 \text { ra }}=10 \mathrm{~Hz}$ and $12 \mathrm{~Hz}$ in $1 \mathrm{a}$ and $1 \mathrm{~b}$, respectively) while the vicinal proton coupling constants of axial-equatorial protons of $1 \mathrm{a}$ are to be larger than those of $1 \mathrm{~b}\left(J_{\mathrm{sabe}}=7 \mathrm{~Hz}\right.$ and $3 \mathrm{~Hz}$ in $\mathbf{1 a}$ and $\mathbf{1 b}, J_{5 e \epsilon_{\mathrm{al}}}=4 \mathrm{~Hz}$ and $3 \mathrm{~Hz}$ in $\mathbf{1 a}$ and $\mathbf{1 b}$. respectively). ${ }^{13}$

We also monitored NMR spectra in various temperatures from $+60^{\circ} \mathrm{C}$ to $-70^{\circ} \mathrm{C}$ in $\mathrm{CDCl}_{3}$ in ${ }^{1} \mathrm{H}$ NMR and from +20 ${ }^{\circ} \mathrm{C}$ to $-80{ }^{\circ} \mathrm{C}$ in $\mathrm{CD}_{2} \mathrm{Cl}_{2}$ in ${ }^{13} \mathrm{C}$ NMR to exclude the possibility that equilibrium state of different conformations in solution could give one confomation in NMR.

As shown in Figure 3, no noticeable change was observed

Table 3. Bond lengths [A] and angles [deg] for 1a and 2

\begin{tabular}{lcc}
\hline & $1 \mathrm{a}$ & $\mathbf{2}$ \\
\hline $\mathrm{S}(1)-\mathrm{O}(1)$ & $1.513(2)$ & $1.432(3)$ \\
$\mathrm{S}(1)-\mathrm{C}(1)$ & $1.812(3)$ & $1.756(4)$ \\
$\mathrm{S}(1)-\mathrm{C}(5)$ & $1.812(2)$ & $1.793(3)$ \\
$\mathrm{O}(2)-\mathrm{C}(10)$ & $1.432(3)$ & \\
$\mathrm{C}(1)-\mathrm{C}(2)$ & $1.519(4)$ & $1.520(5)$ \\
$\mathrm{C}(2)-\mathrm{C}(3)$ & $1.528(3)$ & $1.517(5)$ \\
$\mathrm{C}(3)-\mathrm{C}(4)$ & $1.531(3)$ & $1.539(4)$ \\
$\mathrm{C}(3)-\mathrm{C}(6)$ & $1.548(4)$ & $1.562(5)$ \\
$\mathrm{C}(4)-\mathrm{C}(5)$ & $1.535(3)$ & $1.547(4)$ \\
$\mathrm{C}(5)-\mathrm{C}(10)$ & $1.551(3)$ & $1.553(5)$ \\
$\mathrm{C}(6)-\mathrm{C}(8)$ & $1.527(4)$ & $1.537(5)$ \\
$\mathrm{C}(6)-\mathrm{C}(7)$ & $1.530(4)$ & $1.506(5)$ \\
$\mathrm{C}(6)-\mathrm{C}(9)$ & $1.534(4)$ & $1.503(6)$ \\
$\mathrm{C}(10)-\mathrm{C}(11)$ & $1.533(3)$ & $1.533(5)$ \\
$\mathrm{C}(10)-\mathrm{C}(17)$ & $1.534(3)$ & $1.540(4)$ \\
\hline
\end{tabular}

Table 3. Continued

\begin{tabular}{|c|c|c|}
\hline & $1 \mathrm{a}$ & 2 \\
\hline$C(11)-C(16)$ & $1.377(3)$ & $1.385(5)$ \\
\hline $\mathrm{C}(11)-\mathrm{C}(12)$ & $1.382(4)$ & $1.371(5)$ \\
\hline $\mathrm{C}(12)-\mathrm{C}(13)$ & $1.375(4)$ & $1.400(6)$ \\
\hline $\mathrm{C}(13)-\mathrm{C}(14)$ & $1.377(4)$ & $1.361(7)$ \\
\hline$C(14)-C(15)$ & $1.361(4)$ & $1.356(7)$ \\
\hline$C(15)-C(16)$ & $1.381(4)$ & $1.375(5)$ \\
\hline $\mathrm{C}(17)-\mathrm{C}(18)$ & $1.383(4)$ & $1.379(5)$ \\
\hline$C(17)-C(22)$ & $1.386(4)$ & $1387(4)$ \\
\hline$C(18)-C(19)$ & $1.379(4)$ & $1.375(5)$ \\
\hline $\mathrm{C}(19)-\mathrm{C}(20)$ & $1.369(5)$ & $1.370(5)$ \\
\hline$C(20)-C(21)$ & $1.359(5)$ & $1.368(6)$ \\
\hline $\mathrm{C}(21)-\mathrm{C}(22)$ & $1.391(4)$ & $1.386(5)$ \\
\hline$S(1)-O(2)$ & & $1.438(3)$ \\
\hline$O(3)-C(10)$ & & $1.431(4)$ \\
\hline$O(1)-S(1)-C(1)$ & $107.70(13)$ & $108.4(2)$ \\
\hline$O(1)-S(1)-O(2)$ & & $117.5(2)$ \\
\hline$O(1)-S(1)-C(5)$ & $105.20(11)$ & $111.3(2)$ \\
\hline $\mathrm{C}(1) \mathrm{S}(1)-\mathrm{C}(5)$ & $97.26(12)$ & $104.3(2)$ \\
\hline$O(2)-S(1)-C(5)$ & & $106.1(2)$ \\
\hline $\mathrm{C}(2)-\mathrm{C}(\mathrm{I})-\mathrm{S}(\mathrm{I})$ & $116.8(2)$ & $113.9(3)$ \\
\hline $\mathrm{C}(1)-\mathrm{C}(2)-\mathrm{C}(3)$ & $112.0(2)$ & $112.3(3)$ \\
\hline$C(2)-C(3)-C(4)$ & $109.6(2)$ & $108.8(3)$ \\
\hline$C(2)-C(3)-C(6)$ & $114.3(2)$ & $113.1(3)$ \\
\hline$C(4)-C(3)-C(6)$ & $111.7(2)$ & $112.4(3)$ \\
\hline$C(3)-C(4)-C(5)$ & $116.8(2)$ & $116.8(3)$ \\
\hline$C(4)-C(5)-C(10)$ & $112.1(2)$ & $117.0(3)$ \\
\hline$C(4)-C(5)-S(1)$ & $112.0(2)$ & $107.3(2)$ \\
\hline$C(1 \cup)-C(5)-S(1)$ & $149.4(2)$ & $114.7(2)$ \\
\hline $\mathrm{C}(8)-\mathrm{C}(6)-\mathrm{C}(7)$ & $108.7(3)$ & $106.6(4)$ \\
\hline $\mathrm{C}(8)-\mathrm{C}(6)-\mathrm{C}(9)$ & $109.5(3)$ & $108.4(4)$ \\
\hline $\mathrm{C}(7)-\mathrm{C}(6)-\mathrm{C}(9)$ & $108.0(3)$ & $109.9(4)$ \\
\hline $\mathrm{C}(8)-\mathrm{C}(6)-\mathrm{C}(3)$ & $111.9(3)$ & $109.6(3)$ \\
\hline $\mathrm{C}(7)-\mathrm{C}(6)-\mathrm{C}(3)$ & $109.5(2)$ & $112.1(3)$ \\
\hline$C(9)-C(6)-C(3)$ & $109.1(2)$ & $110.1(3)$ \\
\hline$O(2)-C(10)-C(11)$ & $107.0(2)$ & \\
\hline $\mathrm{O}(2)-\mathrm{C}(10)-\mathrm{C}(17)$ & $109.3(2)$ & \\
\hline$C(11)-C(10)-C(17)$ & $109.7(2)$ & $106.9(2)$ \\
\hline $\mathrm{O}(2)-\mathrm{C}(10)-\mathrm{C}(5)$ & $109.1(2)$ & \\
\hline$C(11)-C(10)-C(5)$ & $108.5(2)$ & $107.7(3)$ \\
\hline$C(17)-C(10)-C(5)$ & $113.1(2)$ & $115.2(3)$ \\
\hline $\mathrm{C}(16)-\mathrm{C}(11)-\mathrm{C}(12)$ & $118.0(2)$ & $118.4(4)$ \\
\hline $\mathrm{C}(16)-\mathrm{C}(11)-\mathrm{C}(10)$ & $121.4(2)$ & $119.2(3)$ \\
\hline$C(12)-C(11)-C(10)$ & $120.6(2)$ & $122.4(3)$ \\
\hline $\mathrm{C}(13)-\mathrm{C}(12)-\mathrm{C}(11)$ & $121.0(3)$ & $119.7(5)$ \\
\hline $\mathrm{C}(12)-\mathrm{C}(13)-\mathrm{C}(14)$ & $120.3(3)$ & $120.5(5)$ \\
\hline$C(15)-C(14)-C(13)$ & $119.2(3)$ & $120.4(5)$ \\
\hline $\mathrm{C}(14)-\mathrm{C}(15)-\mathrm{C}(16)$ & $120.6(3)$ & $119.5(5)$ \\
\hline$C(11)-C(16)-C(15)$ & $120.9(3)$ & $121.5(4)$ \\
\hline $\mathrm{C}(18)-\mathrm{C}(17)-\mathrm{C}(22)$ & $117.6(2)$ & $117.8(3)$ \\
\hline $\mathrm{C}(18)-\mathrm{C}(17)-\mathrm{C}(10)$ & $122.7(2)$ & $117.2(3)$ \\
\hline $\mathrm{C}(22)-\mathrm{C}(17)-\mathrm{C}(10)$ & $119.7(2)$ & $124.8(3)$ \\
\hline $\mathrm{C}(19)-\mathrm{C}(18)-\mathrm{C}(17)$ & $121.2(3)$ & $121.3(3)$ \\
\hline $\mathrm{C}(20)-\mathrm{C}(19)-\mathrm{C}(18)$ & $120.6(3)$ & $120.6(4)$ \\
\hline $\mathrm{C}(21)-\mathrm{C}(20)-\mathrm{C}(19)$ & $119.2(3)$ & $119.1(4)$ \\
\hline $\mathrm{C}(20)-\mathrm{C}(21)-\mathrm{C}(22)$ & $120.8(3)$ & $120.7(4)$ \\
\hline $\mathrm{C}(17)-\mathrm{C}(22)-\mathrm{C}(21)$ & $120.5(3)$ & $120.5(4)$ \\
\hline$O(3)-C(10)-C(5)$ & & $109.4(2)$ \\
\hline$O(3)-C(10)-C(11)$ & & $108.1(3)$ \\
\hline$O(3)-C(10)-C(17)$ & & $109.2(3)$ \\
\hline
\end{tabular}


in spectral patterns except for line broadening at low temperature in ${ }^{\mathrm{H}} \mathrm{H} \mathrm{NMR}$, confirming that 1a adopts a twist boat form in solution as one conformer.

In summary, a stable twist boat conformation of thiane $S$ oxide $1 \mathrm{a}$ in solid state and solution was unambiguously determined by X-ray crystal and solution NMR analyses. respectively. This is the first example where a twist boat form is experimentally observed as a preferred structure in the thiane $S$-oxide system. In contrast, the corresponding thiane $S$-dioxide 2 produced by the oxidation of thiane $S$ oxide 1a was confirmed to adopt a chair form. Further studies to prepare other stable nonchair conformers are underway in our laboratory.

Acknowledgments. We thank Korea Research Institute of Chenical Technology for generous financial support

\section{References}

1. (a) Hendrickson. J. B. J. Am. Chem. Soc, 1961, 83, 4537. (b) Beckett. C. W.: Pitzer. K. S.: Spitzer. R. J. Am. Chem. Soc. 1947. 69. 2488. (c) Beckett. C. W.: Freeman. N. K.: Pitzer. K. S. J. Am. Chem. Soc. 1948. 70, 4227. (d) Turner. R. B. J. Am. Chem. Soc. 1952, 7f, 211. (e) Howlett. K. E. J. Chem. Soc. 1957, 4353 .

2. (a) Johnson, W. S.: Margrave. J. L.: Balcer. V. J. Frish. M. A.: Dreger. L. H. Hubbard. W. N. J. Am Chem. Soc 1960.82, 1255 (b) Allinger. N. L.: Freiberg. L. A. J. Ant. Chent. Soc. 1960. 82.2393.

3. (a) Hutchins. R. O.: Maryanoff. B. E.: Castillo. M. J: Hargrave. K. D.: McPhail. A. T. J. Am. Chen. Soc. 1979. 101. 1600. (b) Bajwa G. S.: Bentrude. W. G. Pantaleo. N. S.: Newton. M. G.: Hargis. I. H. J. Am. Chem. Soc. 1979, 101. 1602. (c) Ramalingam, K.: Berlin, K. D.: Powell, D. R.: Helm. D. J. Ong. Chem, 1987, 52. 2108 .

4. For the synthesis of trans-4-tert-butylthiane $S$-oxide. see: Johnson.
C. R.: McCants. D. Ir. $J$. Am. Chent Soc. 1965. 87.1109.

5. For the stereochemistry to the electrophilic reaction of cyclic $\alpha$ lithio sulfoxides. see: Chassaing. G.: Lett. R.: Marquet. A. Tetrohedron Lett. 1978. 471 , and references therein.

6. CCDC 651189 and CCDC 651188 contain the supplementary erystallographic data for compounds 1 a and 2 . respectively. These data can be obtained fiee of charge from The Cambridge Crystallographic Data Centre via www.cedc.cam.ac.uk data_request cif.

7. Freemant. F.: Asgari. N.: Entezam. B.: Gomarooni. F.: Mac. T.: Nguyen. M. H.: Nguyen. N. N. T:; Nguyen, T. P.: Pham, N. B: Sultana, P.: Welch, T. S.: Shainyan. B. A. Iht d. Quantum Chem. 2005. 101,40

8. (a) Lambert. J. B.: Keske. R. G. J. Org. Chem. 1966. 31. 3429. (b) Allinger. N. L.: Kao. T. Tetrahedron 1976. 32.529. (c) Allinger. N. A.: Hirsh. T. A.: Miller. M. A.: Tyminski. L. T. J. Am. Chent. Soc. $1969.91,337$

9. For the twist boat conformations by hydrogen bonding. see: (a) Stolow, R. D. J. Am. Chem. Soc. 1961.83, 2592. (b) Wolfe. J. J: Nelsont. S. F.: Powell. D. R. J. Org. Chem. 1991. 56.5908.

10. If the thiane S-oxide ring of la would adopt a chair form. the sulfoxide should be oriented equatorially

11. Chemical shifts of adjacent $\alpha$-carbons and protons of axial type sulfoxide in the thiane $S$-oxide ring appear at upfield in comparison with those of equatorial type sulfoxide; see: (a) Buchanan. G. W: Durst. T. Tetrahedron Lett. 1975. 1683. (b) Lett. R: Marquet. A. Tetrahedron 1974. 30. 3379. (c) Lett. R.: Marquet. A. Tetrahedron Lett. 1975. 1579

12. For the anisotropy of sulfoxide, see: (a) Poster. A. B.: Duxbury: J. M: Inch, T. D: Webber, J. M. Chem. Comm. 1967. 881. (b) Edmundson. R. S. Tetrahedron Lett. 1965, 1649.

13. From vicinal proton coupling constants by the Karplus method. $R$ value could be calculated and the structural conformation pro-

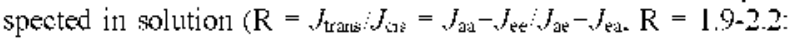
usual chair form, 1.9: twist boat. 2.2: puckered chair). In 1a and

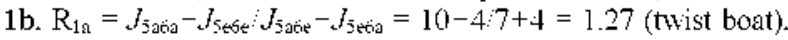

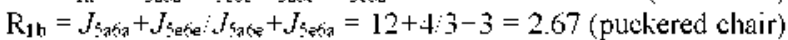
see. (a) Lambert. J. B. Acc. Chem. Res. 1971. f. 87. (b) Lambert. J. B. J.Ant Chent Soc. 1967. 89. 1836. 